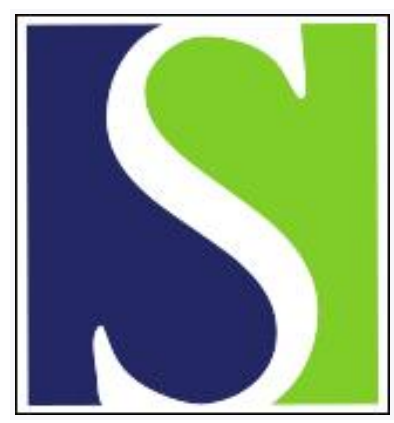

Scand J Work Environ Health 2009;35(1):56-64

https://doi.org/10.5271/sjweh.1302

Published online: 20 Feb 2009, Issue date: 00 Jan 2009

Musculoskeletal disorders among construction roofers-physical function and disability

by Welch L, Haile E, Boden LI, Hunting KL

Affiliation: The Center for Construction Research and Training, 8484 Georgia Ave, Suite 1000, Silver Spring, MD 20910, USA. Iwelch@cpwr.com

Refers to the following texts of the Journal: 2005;31(4):249-257 2005;31 suppl 2:31-36 2006;32(1):75-84 2007;33(5):351-357 1997;23(6):403-413

The following articles refer to this text: 2009;35(5):321-324; 2010;36(1):1-2; 2011;37(6):451-453

Key terms: construction; construction roofer; disability; job accommodation; longitudinal study; low-back pain; MSD; musculoskeletal disorder; occupation; physical function; work ability; work limitation

This article in PubMed: www.ncbi.nlm.nih.gov/pubmed/19229441 


\title{
Musculoskeletal disorders among construction roofers—physical function and disability
}

\author{
by Laura Welch, MD, ${ }^{1}$ Elizabeth Haile, MS, ${ }^{1}$ Leslie I Boden, PhD, ${ }^{2}$ Katherine L Hunting, PhD ${ }^{3}$
}

\begin{abstract}
Welch L, Haile E, Boden LI, Hunting KL. Musculoskeletal disorders among construction roofers—physical function and disability. Scand J Work Environ Health. 2009;35(1):56-63

Objectives This study investigated the relationships between work demands, chronic medical and musculoskeletal conditions, aging, and the ability to remain on the job in a longitudinal study of 979 construction roofers between the ages of 40 and 59 years.

Methods In a phone interview at baseline and 1 year later, the participants were asked about the presence of medical conditions and musculoskeletal disorders, work limitations and work accommodations, and social and economic functioning.

Results Among the workers for whom a musculoskeletal disorder was their most serious condition at baseline, $8 \%$ left roofing due to a health condition during the first year of follow-up. A comparison between those who left and those who stayed identified older age and lower physical functioning as statistically significant predictors of leaving the trade. Workers with a musculoskeletal disorder and who, in the baseline interview, reported receiving some type of job accommodation for their musculoskeletal disorder had an odds ratio of $0.24(\mathrm{P}=0.07)$ for leaving work by the time of the 1-year follow-up when compared with workers with a musculoskeletal disorder and no job accommodation. The workers with three or more work limitations were also more likely to leave roofing, but this association disappeared after adjustment for other factors.

Conclusions Musculoskeletal conditions among roofers are strongly associated with work limitation, missed work, and reduced physical functioning, factors that are predictive of premature departure from the workforce. Job accommodation was provided for $31 \%$ of the roofers with a musculoskeletal disorder, and it was associated with a reduced likelihood of subsequently leaving roofing for health-related reasons.
\end{abstract}

Key terms injury; job accommodation; low-back pain; longitudinal study; occupation; work ability; work limitation.

The physically demanding nature of the work in construction, which includes manual materials handling, awkward and static postures, vibration, and a harsh outdoor environment, helps explain why strain and sprain are the most common types of work-related injury in construction, accounting for over 35\% of all injuries resulting in days away from work $(1,2)$. Cross-sectional studies reveal a high prevalence of chronic musculoskeletal symptoms among construction workers (3-6). In addition, construction workers are less likely to return to work after a musculoskeletal injury than workers in other occupations (7-10) and are more likely to retire with a disability $(11,12)$. Our study was undertaken to explore what health or job characteristics predict disability among roofers with musculoskeletal disorders, as indicated by a self-report of leaving work for healthrelated reasons.

\section{Study population and methods}

We enrolled 979 roofers in a longitudinal study and followed up 773 (79\%) of them 1 year later (13). Our goal at baseline was to enroll 1000 active roofers between the ages of 40 and 59 years. The Roofers International Union provided us with contact information for all union members as of March 2004, and we randomly sampled

1 The Center for Construction Research and Training, Silver Spring, Maryland, United States.

2 Boston University School of Public Health, Boston, Massachusetts, United States.

3 Department of Environmental and Occupational Health, George Washington University School of Public Health and Health Services, Washington DC, United States.

Reprint requests to: Dr L Welch, The Center for Construction Research and Training, 8484 Georgia Ave, Suite 1000, Silver Spring, MD 20910, United States. [E-mail: 1welch@cpwr.com] 
3000 persons who (i) were between 40 and 59 years of age with roughly equal numbers from the age groups $40-44,45-49,50-54$, and 55-59 years and (ii) had maintained continuous union membership during the previous 2 years. At the time of the interview, we found that 51 were no longer union members, 8 were deceased, and 1200 could not be contacted by telephone. Of the 1808 roofers contacted, 239 were not eligible because they were not working as a roofer or roofing supervisor or expected to be so employed in the next 3 months. Among the 1569 persons who met this final criterion, $979(62 \%)$ completed an interview. There was no significant difference in the participation rates between the age groups.

The baseline interview included questions on medical and musculoskeletal conditions experienced by the respondents in the prior 2 years and on missed work and job accommodations related to these conditions. For musculoskeletal disorders, we asked "In the past 2 years did you take medication for or need to regularly see a doctor for neck or upper back problems?" and eight other body areas, with additional questions to elicit a specific diagnosis for each body area reported. We used the Short Form-12 (SF-12) (14) questionnaire, eight items from the Work Limitations Questionnaire (15), and a series of questions developed and validated by Pransky et al (16) to assess social and economic changes in the past 12 months and questions from Keogh et al (17) on job accommodation. We classified each participant as having none, $1-2$, or $\geq 3$ limitations according to responses to the Work Limitations Questionnaire.

For each worker we classified one condition as his or her most serious condition. If a roofer reported missing work for only one condition, it was classified as the most serious. Roofers with multiple conditions who did not miss work or who missed work for more than one condition were asked to specify the most serious condition. If the most serious condition was a musculoskeletal disorder, the worker was asked about the frequency and duration of symptoms in the year prior to the interview. The 1-year interview assessed whether the respondents were still actively employed as a roofer, if they had any new medical conditions, if prior or new conditions interfered with their ability to work, and again asked about job accommodations and functional status.

In the first interview, we asked the workers what action their employers took as a direct result of their most serious condition and specifically asked whether their employers changed their work schedule, modified their job tasks, put them on light duty, changed the pace or speed of their jobs, or changed any equipment or tools. If a respondent answered that the employer did not make such an accomodation, we inquired whether the worker had asked for any accomodation. Among the roofers for whom a musculoskeletal disorder was the most serious condition, we created the following three groups: lower back-sciatica, other lower-body musculoskeletal disorders, which included hip, knee and ankle, and upper-body musculoskeletal disorders, including neck or upper back, shoulder, elbow or forearm, hand or wrist and finger or thumb. We asked the workers with a musculoskeletal disorder if they thought their condition was work-related, and, if so, if they had filed a claim for workers' compensation. Only three of our participants were women. They were included in all of the analyses, and data for them are not presented separately.

\section{Statistical analysis}

Comparisons for continuous variables were performed using the Student t-test for normally distributed data or the Wilcoxon rank sum test for nonparametric data. The analysis of variance (ANOVA) method was used for parametric continuous variables, and the Kruskal-Wallis test was used for nonparametric data when means of more than two groups were compared. Dichotomous variables were compared using the chi-square test for general association. The Cochran-Mantel-Haenszel test was used for $\mathrm{s} \times \mathrm{r}$ tables. Ordinal data were compared using the Cochran-Armitage test for trends. We employed a $\mathrm{P}=0.05$ cutoff for statistical significance.

Of the 12 items in the SF-12 measure of health status, 5 items were used to create four subscales. Data were transformed to a norm-based score (NBS) system (14), a linear transformation of the scores to achieve a mean of 50 and a standard deviation of 10 in the general United States population. Lower SF-12 scores indicated a less favorable health status. Since the four SF-12 subscale scores were highly correlated, each of them was assessed in a bivariable model as a predictor of leaving roofing. Physical functioning was the strongest predictor and was chosen for inclusion in the multivariable model. The tables present the median (25th-75th percentile) scores. Because the distribution of physical function had only a few values, the medians of subgroups were sometimes identical. Even so, the distributions may have been significantly different, as reflected by the P-values.

A multivariable regression model was used to determine predictors of leaving roofing. Because our statistical power was limited, predictors with P-values of $<0.20$ were included in the final logistic model when the model building used a forward selection method. In addition, predictors that were deemed significant $(\mathrm{P}<0.20)$ in the univariate analysis of current versus former roofers were included in the final model. A model fit analysis was evaluated with the use of the Hosmer-Lemeshow goodness-of-fit statistical analysis. The C-statistic is reported as a measure of predictive power. All of the statistical analyses were performed with SAS for Windows, version 9.1 (18). 


\section{Results}

\section{Baseline analysis}

Altogether $10 \%$ of our 979 baseline participants were Hispanic, and $11 \%$ were members of a racial minority. There was no association between ethnicity or race and either age or the prevalence of health conditions. When compared with national data on race and ethnicity among construction workers, the race and ethnicity of this group was reasonably representative of all construction roofers (19).

A total of $69 \%$ of the respondents had experienced at least one target medical or musculoskeletal condition in the previous 2 years. Altogether 529 (54\%) of the participants reported at least one musculoskeletal disorder. The total number of conditions reported by any one person ranged from one to nine, $42 \%$ of participants reporting multiple conditions and $28 \%$ reporting multiple musculoskeletal disorders.

A musculoskeletal disorder was the most serious condition for 442 roofers, among whom $38 \%$ had an upper-body musculoskeletal disorder, $37 \%$ had a lowback condition or sciatica, and $26 \%$ had a lower-body musculoskeletal disorder. Altogether 79\% of the roofers reported that their musculoskeletal disorder was workrelated, and, of this group, $27 \%$ had filed for workers' compensation. Roofers with a musculoskeletal disorder as their most serious condition had lower physical functioning than those with no conditions, and they were also more likely to have $\geq 3$ work limitations, particularly those with lower-back pain or sciatica (table 1). Roofers with musculoskeletal disorders reported more frequent limitations during lifting, carrying or moving, bending, twisting or reaching, and repeated movements than did workers with no conditions (table 2); $29 \%$ of those with lower-back pain or sciatica had trouble bending, twisting, and reaching as needed on the job. Roofers with a musculoskeletal disorder who reported symptoms that were frequent or of long duration were significantly more likely to have lower physical functioning and more work limitations and to have missed work in the prior 2 years than those with a musculoskeletal disorder and symptoms with an infrequent or short duration (data not shown).

Some of the roofers with musculoskeletal disorders had received some accommodation prior to the initial interview $(\mathrm{N}=130)$, a small number received no accomodation even though they asked for it $(\mathrm{N}=15)$, and many received no accomodation and had not asked for it $(\mathrm{N}=281)$ (table 3). Those who had missed work or had $\geq 3$ work limitations were more likely to have received an accomodation. The workers who reported that their musculoskeletal disorders were work-related

Table 1. Comparison of the baseline characteristics of the roofers with and without a musculoskeletal disorder (MSD) or medical condition..$^{\mathrm{a}, \mathrm{b}}$

\begin{tabular}{|c|c|c|c|c|c|c|c|c|c|c|c|c|c|}
\hline \multirow[t]{3}{*}{ Characteristic } & \multirow{2}{*}{\multicolumn{3}{|c|}{$\begin{array}{l}\text { No medical or MSD condition } \\
\qquad(\mathrm{N}=302)\end{array}$}} & \multicolumn{9}{|c|}{ Most serious condition } & \multirow[t]{3}{*}{ P-value ${ }^{c}$} \\
\hline & & & & \multicolumn{3}{|c|}{$\begin{array}{l}\text { Upper-body MSD } \\
\qquad(\mathrm{N}=166)\end{array}$} & \multicolumn{3}{|c|}{$\begin{array}{l}\text { Other lower-body MSD } \\
\qquad(\mathrm{N}=113)\end{array}$} & \multicolumn{3}{|c|}{$\begin{array}{l}\text { Lower-back or sciatica } \\
\qquad(\mathrm{N}=163)\end{array}$} & \\
\hline & $\%$ & Median & $\begin{array}{l}\text { 25th-75th } \\
\text { percentile }\end{array}$ & $\%$ & Median & $\begin{array}{l}\text { 25th-75th } \\
\text { percentile }\end{array}$ & $\%$ & Median & $\begin{array}{l}\text { 25th-75th } \\
\text { percentile }\end{array}$ & $\%$ & Median & $\begin{array}{l}\text { 25th-75th } \\
\text { percentile }\end{array}$ & \\
\hline Physical functioning & . & 56.5 & $56.5-56.5$ & . & 56.5 & $47.9-56.5$ & . & 47.9 & $39.3-56.5$ & & 47.9 & $39.3-56.5$ & $<0.01^{d}$ \\
\hline Age categories & $\cdot$ & . & . & $\cdot$ & . & . & . & . & . & . & . & . & 0.04 \\
\hline 40-44 years & 29 & . & . & 26 & . & . & 17 & . & . & 28 & . & . & . \\
\hline $45-49$ years & 28 & . & . & 27 & . & . & 27 & . & . & 37 & . & . & . \\
\hline $50-54$ years & 26 & . & . & 28 & . & . & 29 & . & . & 17 & . & . & . \\
\hline$\geq 55$ years & 18 & . & . & 19 & . & . & 27 & - & . & 18 & . & . & - \\
\hline Work limitations & & - & - & & - & - & - & - & - & & - & - & $<0.01$ \\
\hline None & 63 & . & . & 51 & . & . & 51 & . & . & 45 & . & . & . \\
\hline $1-2$ & 33 & . & . & 40 & . & . & 40 & . & . & 35 & . & . & . \\
\hline$\geq 3$ & 4 & . & . & 9 & . & . & 9 & . & . & 21 & . & . & . \\
\hline $\begin{array}{l}\text { Frequent or long duration } \\
\text { (versus infrequent or } \\
\text { short duration) }\end{array}$ & . & . & $\cdot$ & 66 & $\cdot$ & . & 70 & $\cdot$ & . & 70 & . & $\cdot$ & $0.68^{e}$ \\
\hline $\begin{array}{l}\text { Any missed work (versus } \\
\text { no missed work) }\end{array}$ & 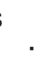 & . & $\cdot$ & 39 & $\cdot$ & . & 46 & . & . & 50 & . & $\cdot$ & $0.12^{\mathrm{e}}$ \\
\hline
\end{tabular}

a Five participants who were nonresponsive to $\geq 4$ of the work-limitation questions were excluded from the analysis of work limitations, and fifteen who were nonresponsive or with DK answers for the severity questions were excluded from the analysis of the frequency or length of duration.

b Some responses do not add up to $100 \%$ due to rounding.

c All comparisons were made using the Cochran-Mantel-Haenszel test unless noted otherwise.

a Kruskal-Wallis test.

e Chi-square test. 
Table 2. Prevalence of work limitations for roofers with a musculoskeletal disorder (MSD) as the most serious condition and for roofers with no medical condition or musculoskeletal disorder.a, b

\begin{tabular}{|c|c|c|c|c|}
\hline \multirow[t]{3}{*}{ Question asked } & \multicolumn{4}{|c|}{ Negative responses } \\
\hline & \multirow{2}{*}{$\begin{array}{c}\text { No medical or } \\
\text { MSD condition } \\
(\mathrm{N}=302)(\%\end{array}$} & \multicolumn{3}{|c|}{ Most serious condition } \\
\hline & & $\begin{array}{c}\text { Upper-body } \\
\text { MSD } \\
(\mathrm{N}=166) \\
(\%)\end{array}$ & $\begin{array}{c}\text { Other lower-body } \\
\text { MSD } \\
(\mathrm{N}=113 \\
(\%)\end{array}$ & $\begin{array}{c}\text { Lower-back } \\
\text { or sciatica } \\
(\mathrm{N}=163) \\
(\%)\end{array}$ \\
\hline 1. Are you able to do all of the work you need to do without stopping to take breaks or rest? & 28 & 36 & 36 & 37 \\
\hline 2. Are you able to lift, carry, or move the objects you need at work? & 8 & 16 & 17 & 23 \\
\hline 3. Are you able to walk or move around to different locations at work when you need to? & 3 & 4 & 7 & 12 \\
\hline 4. Are you able to bend, twist, or reach as much as you need to? & 5 & 10 & 16 & 29 \\
\hline 5. Are you able to concentrate on your work? & 1 & 5 & 2 & 8 \\
\hline 6. Do you see and hear well enough to do all your work tasks? & 2 & 4 & 4 & 6 \\
\hline 7. Are you able to use handheld tools, pens, or computer equipment as you need to? ${ }^{c}$ & 4 & 6 & 2 & 5 \\
\hline 8. Are you able to make the same movements repeatedly as much as you need to? ${ }^{\mathrm{d}}$ & 2 & 6 & 8 & 12 \\
\hline
\end{tabular}

a One respondent was excluded due to missing data.

${ }^{\text {b }}$ Some responses do not add up to $100 \%$ due to rounding.

${ }^{c} \mathrm{~N}=701$ since only those who used handheld tools were asked how often they were able to use handheld tools.

${ }^{d} \mathrm{~N}=645$ since only those who make the same movements repeatedly were asked how often they were able to do these same movements.

Table 3. Association between the baseline characteristics and job modification among the roofers with a musculoskeletal disorder (MSD) as the most serious condition $(\mathrm{N}=426)$. a, b

\begin{tabular}{|c|c|c|c|c|c|c|c|c|c|c|c|c|c|c|c|c|}
\hline \multirow[t]{2}{*}{ Characteristic } & \multicolumn{5}{|c|}{ Any modification $(\mathrm{N}=130)$} & \multicolumn{5}{|c|}{$\begin{array}{l}\text { No modification, } \\
\text { asked for one }(\mathrm{N}=15)\end{array}$} & \multicolumn{5}{|c|}{$\begin{array}{c}\text { No modification, } \\
\text { did not ask for one }(\mathrm{N}=281)\end{array}$} & \multirow[t]{2}{*}{ P-value } \\
\hline & $\mathrm{N}$ & SD & $\%$ & Median & $\begin{array}{l}\text { 25th-75th } \\
\text { percentile }\end{array}$ & $\mathrm{N}$ & SD & $\%$ & Median & $\begin{array}{l}\text { 25th-75th } \\
\text { percentile }\end{array}$ & $\mathrm{N}$ & SD & $\%$ & Median & $\begin{array}{l}\text { 25th-75th } \\
\text { percentile }\end{array}$ & \\
\hline Age & 48.5 & 5.6 & $\cdot$ & . & $\cdot$ & 521 & 3.9 & $\cdot$ & . & $\cdot$ & 49.7 & 5.5 & . & $\cdot$ & . & $0.02^{c}$ \\
\hline Physical functioning & . & . & $\cdot$ & 56.5 & $39.3-56.5$ & - & . & . & 39.3 & $30.7-56.5$ & . & & . & 56.5 & $47.9-56.5$ & $0.01^{d}$ \\
\hline Missed work & . & . & . & . & - & . & . & . & . & . & . & & . & . & . & $<0.01^{e}$ \\
\hline Yes & . & . & 57 & . & . & . & . & 53 & . & . & . & & 36 & . & . & . \\
\hline No & . & . & 43 & . & . & - & . & 47 & . & . & . & & 64 & . & . & . \\
\hline Work limitations & . & . & $\cdot$ & . & - & . & . & - & . & . & . & & . & . & . & $<0.01^{f}$ \\
\hline None $(\mathrm{N}=205)$ & . & . & 45 & . & . & . & . & 20 & . & . & . & & 51 & . & . & . \\
\hline $1-2(\mathrm{~N}=164)$ & . & . & 38 & . & . & . & . & 27 & . & . & . & & 40 & . & . & . \\
\hline$\geq 3(N=54)$ & . & . & 16 & . & . & . & . & 53 & . & . & . & & 9 & . & . & . \\
\hline
\end{tabular}

a There were 16 respondents with missing information on job accommodation and 2-3 respondents with missing information for some of the listed characteristics.

b Some responses do not add up to $100 \%$ due to rounding.

${ }^{c}$ Analysis of variance (ANOVA).

a Kruskal-Wallis test.

${ }^{\mathrm{e}}$ Chi-square test.

${ }^{\dagger}$ Cochran-Mantel-Haenszel test.

were twice as likely to receive accomodations as those with nonwork-related musculoskeletal disorders (34\% versus $17 \%$, respectively, data not shown).

\section{One-year interview}

Among the roofers for whom a musculoskeletal disorder $(\mathrm{N}=442)$ was the most serious condition, we completed a second interview with 362 (82\%) persons. Among them, 29 had stopped working as a roofer for health-related reasons, and 318 were still working as a roofer at the time of the follow-up. Table 4 compares their characteristics, excluding 15 who left roofing for nonhealthrelated reasons. The roofers with a musculoskeletal disorder who left for a health-related reason were older than those who continued to work, had significantly lower physical functioning, and were significantly more likely to have had $\geq 3$ work limitations at the baseline. Those who stayed at work were significantly more likely to have received a job modification than those who neither received a job accommodation nor asked for it; those who asked for a modification, but did not receive it, were significantly more likely to leave work. 
Table 4. Unadjusted predictors of leaving roofing due to a health-related reason for 347 roofers with a musculoskeletal disorder (MSD) as their most serious baseline condition. ${ }^{\text {a }}$

\begin{tabular}{|c|c|c|c|c|c|c|c|c|c|c|c|}
\hline \multirow[t]{2}{*}{ Predictor } & \multicolumn{5}{|c|}{ Current roofers ( $N=318)$} & \multicolumn{5}{|c|}{ Former roofers $(\mathrm{N}=29)$} & \multirow[t]{2}{*}{ P-value } \\
\hline & $\%$ & Mean & SD & Median & $\begin{array}{l}\text { 25th-75th } \\
\text { percentile }\end{array}$ & $\%$ & Mean & SD & Median & $\begin{array}{l}\text { 25th-75th } \\
\text { percentile }\end{array}$ & \\
\hline Age & . & 49.2 & 5.3 & . & . & . & 53.8 & 4.7 & . & . & $<0.01^{b}$ \\
\hline Physical functioning & . & . & . & 56.5 & $47.9-56.5$ & . & . & . & 39.3 & $22.1-47.9$ & $<0.01^{c}$ \\
\hline Type of MSD condition & . & . & . & . & . & . & . & . & . & . & $0.30^{d}$ \\
\hline Upper-body MSD & 37 & . & . & . & . & 28 & . & . & . & . & . \\
\hline Other lower-body MSD & 25 & . & . & . & . & 38 & . & . & . & . & . \\
\hline Lower-back or sciatica & 37 & . & . & . & . & 34 & . & $\cdot$ & . & . & . \\
\hline $\begin{array}{l}\text { Frequent or long duration (versus infrequent or } \\
\text { short duration) }\end{array}$ & 67 & . & . & . & . & 79 & . & . & . & . & $0.19^{d}$ \\
\hline $\begin{array}{l}\text { Any missed work (versus no missed work) in } \\
2 \text { years prior to baseline }\end{array}$ & 44 & . & . & . & . & 55 & . & . & . & . & $0.26^{d}$ \\
\hline Work limitations & . & . & . & . & . & . & . & . & . & . & $0.01^{\mathrm{e}}$ \\
\hline None & 50 & . & . & . & . & 30 & . & . & . & . & . \\
\hline $1-2$ & 37 & . & . & . & . & 41 &. & . & . & . & . \\
\hline$\geq 3$ & 13 & . & . & . & . & 30 & . & . & . & . & . \\
\hline Job accommodations & . & . & . & . & . & . & . & . & . & . & $<0.01^{d}$ \\
\hline Any modification & 32 & . & . & . & . & 13 & . & . & . & . & . \\
\hline No modification, asked employer & 4 & . & . & . & . & 17 & . & . & . & . & . \\
\hline No modification, did not ask employer & 65 & . & . & . & . & 70 & . & . & . & . & . \\
\hline
\end{tabular}

a Fourteen respondents were missing information on job accommodations, eight respondents were missing frequency or length of duration information, one to four respondents were missing information for some of the listed characteristics.

${ }^{\mathrm{b}}$ Student t-test.

c Wilcoxon rank sum test.

d Chi-square test.

${ }^{e}$ Cochran-Armitage trend test.

Table 5. Adjusted predictors of leaving roofing due to a healthrelated reason among 347 roofers with a musculoskeletal disorder (MSD) as their most serious baseline condition. (OR = odds ratio, $95 \% \mathrm{Cl}=95 \%$ confidence intervals)

\begin{tabular}{|c|c|c|c|}
\hline Predictor & $\mathrm{OR}$ & $95 \% \mathrm{Cl}$ & P-value a \\
\hline Age (years) & 0.15 & $1.04-1.27$ & 0.01 \\
\hline $\begin{array}{l}\text { Physical functioning (1 point on } \\
\text { norm-based scale) }\end{array}$ & 0.93 & $0.89-0.98$ & 0.01 \\
\hline \multicolumn{4}{|c|}{ Job accommodation (versus no accommodation and did not ask for one } \\
\hline $\begin{array}{l}\text { Any job accommodation } \\
\text { No job accommodation and } \\
\text { asked for one }\end{array}$ & $\begin{array}{l}0.24 \\
2.32\end{array}$ & $\begin{array}{l}0.05-1.15 \\
0.54-10.03\end{array}$ & $\begin{array}{l}0.07 \\
0.26\end{array}$ \\
\hline $\begin{array}{l}\text { Frequent or long duration MSD } \\
\text { symptoms (versus infrequent or } \\
\text { short duration) }\end{array}$ & 1.11 & $0.35-3.51$ & 0.85 \\
\hline \multicolumn{4}{|c|}{ Work limitations (versus no work limitations) } \\
\hline $\begin{array}{l}1-2 \text { work limitations } \\
\geq 3 \text { work limitations }\end{array}$ & $\begin{array}{l}1.07 \\
1.00\end{array}$ & $\begin{array}{l}0.32-3.59 \\
0.21-4.77\end{array}$ & $\begin{array}{l}0.92 \\
0.99\end{array}$ \\
\hline
\end{tabular}

a Hosmer \& Lemeshow goodness-of-fit test: chi-square $=4.22, \mathrm{df}=8$, $\mathrm{P}=0.84$, C-statistic $=0.84$.

In a multivariable logistic analysis (table 5), age and physical functioning at baseline remained predictive of leaving roofing; each year an increase in age was associated with a $15 \%$ increase in the likelihood of leaving work, and each point of improvement in physical functioning was associated with a $7 \%$ decrease in the likelihood of leaving. Neither the type of musculoskeletal disorder nor the frequency and severity of symptoms was significantly associated with an increased likelihood of leaving in this model. Those who had received a job accommodation had an odds ratio of 0.24 for leaving work $(95 \%$ confidence interval $0.05-1.15)$ in the multivariate model, and those who asked for a modification but did not get it had an odds ratio of 2.32 for leaving (95\% confidence interval 0.54-10.03).

\section{Discussion}

Back pain and other musculoskeletal injuries are costly with respect to medical care, wage loss, productivity, disability, and diminished quality of life. In this study we found that (i) there was a significant burden of musculoskeletal disorders among construction roofers who were aged 40-59 years and were actively employed; (ii) many construction workers continued to work with pain; (iii) among the workers with a musculoskeletal disorder as their most serious condition and interviewed 1 year later, $8 \%$ left roofing due to health-related reasons during the first year of follow-up; (iv) age and physical 
functioning at baseline were predictors of the decision to leave roofing; and (v) workers who received some type of job accommodation had an odds ratio of 0.24 $(\mathrm{P}=0.07)$ for leaving work when compared with workers with a medical condition and no job accommodation.

The prevalence of musculoskeletal disorders among these roofers was consistent with the results of prior studies reporting a high rate of continuing symptoms after an episode of acute low-back pain in the general population (20-24), among workers with occupational low-back pain $(22,25,26)$, and among construction workers with musculoskeletal disorders (27). Many workers with musculoskeletal disorders continue to work with pain (28-30) and report residual effects on work or daily living (28).

Recognized risk factors for disability retirement among a range of occupations include older age, the presence of a musculoskeletal disorder, severity of the injury, greater pain and functional disability, a low work ability index, sick leave of $>7$ days of work, physically demanding work, lack of job accommodation, lack of coworker support, and low expectations of recovery (31-38). Physical workload is an important determinant of work ability among construction workers (39), and work ability is highly predictive of disability among all workers and specifically among construction workers $(40,41)$. Consistent with prior research, work limitations at the baseline in this population were predictive of leaving work 1 year later; this association was eliminated once other predictors were accounted for.

In our analysis, the type of musculoskeletal disorder was not predictive of leaving roofing, although prior research suggests that workers with low-back pain or sciatica have a higher likelihood of leaving work $(7,36$, 42). Our workers with low-back pain or sciatica did have lower physical functioning and more work limitations. The final model suggested that physical functioning is a more important measure than a specific medical diagnosis or work limitations, but, since the SF-12 measures are correlated with work limitations and our sample size was small, our power to characterize the independent role of each factor was limited.

In this analysis we chose to focus on a subset of roofers with musculoskeletal disorders, those for whom the musculoskeletal disorder was their most serious condition; more details on the impact of all of the musculoskeletal disorders and of the medical conditions can be found in prior reports $(13,43)$. Given that some workers with musculoskeletal disorders change occupations or leave the workforce shortly after condition onset, no cross-sectional group of workers is representative of all workers ever-employed in construction. This group is reasonably representative, however, of working roofers aged 40-59 years, the group at risk for disability retirement $(31,44,45)$. All of the measures used in our study were self-reported. To reduce reporting bias, we used widely accepted tools to assess physical function and work limitations and ones validated in prior research to assess job accommodation and symptoms of musculoskeletal disorders, but we were not able to validate the reported musculoskeletal disorders or job accommodation with other measures.

A total of $31 \%$ of the roofers in our study received job accommodation, and accommodation may prevent leaving work for a health-related reason. This finding should be interpreted cautiously, since the odds ratio of 0.24 did not reach statistical significance at the 0.05 level and our statistical power was limited. Returnto-work programs have been shown to be effective in reducing costs and work absence in other industrial sectors (46-49).

The identification of risk factors for leaving the roofing trade is important if the knowledge leads to work modification, a change in work organization, or some modification of the risk factors to prevent disability. Burdorf et al (45) estimated that a construction worker with a low work ability index, severe low-back pain, and an age of 45-54 years had a 40-fold increase in the probability of disability retirement when compared with a young construction worker without these risk factors. They proposed that specific intervention programs be developed for construction workers with a 4-year probability of disability retirement between 0.20 and 0.38 . Like Burdorf et al, we identified age, work limitations, and the presence of reduced physical functioning as risk factors for leaving work due to a health problem. This study also shows that job accommodation is feasible in the United States construction industry.

\section{Acknowledgments}

This work was performed under a grant to the Center to Protect Workers' Rights (CPWR), RO1OH00369/ NIOSH. This research is solely the responsibility of the authors and does not necessarily represent the views of CPWR or the National Institute for Occupational Safety and Health (NIOSH).

\section{References}

1. Schneider SP. Musculoskeletal injuries in construction: a review of the literature. Appl Occup Environ Hyg. 2001;16(11):1056-64.

2. CPWR: The Center for Construction Research and Training. The construction chart book: the US construction industry and its workers. Silver Spring (MD): CPWR; 2007. p 40

3. Merlino LA, Rosecrance JC, Anton D, Cook TM. Symptoms 
of musculoskeletal disorders among apprentice construction workers. Appl Occup Environ Hyg. 2003;18(1):57-64.

4. Holmstrom E, Engholm G. Musculoskeletal disorders in relation to age and occupation in Swedish construction workers. Am J Ind Med. 2003;44(4):377-84.

5. Goldsheyder D, Weiner SS, Nordin M, Hiebert R. Musculoskeletal symptom survey among cement and concrete workers. Work. 2004;23(2):111-21.

6. Hunting KL, Welch LS, Cuccherini BA, Seiger LA. Musculoskeletal symptoms among electricians. Am J Ind Med. 1994;25(2):149-63.

7. Oleinick A, Gluck JV, Guire K. Factors affecting first return to work following a compensable occupational back injury. Am J Ind Med 1996;30(5):540-55.

8. Turner JA, Franklin G, Turk DC. Predictors of chronic disability in injured workers: a systematic literature synthesis. Am J Ind Med. 2000;38:707-22.

9. Rossignol M, Suissa S, Abenhaim L. Working disability due to occupational back pain: three-year follow-up of 2,300 compensated workers in Quebec. J Occup Med. 1988;30(6):502-5.

10. McIntosh G, Frank J, Hogg-Johnson S, Bombardier C, Hall H. Prognostic factors for time receiving workers' compensation benefits in a cohort of patients with low back pain. Spine. 2000;25(2):147-57.

11. Brenner H, Ahern W. Sickness absence and early retirement on health grounds in the construction industry in Ireland. Occup Environ Med. 2000;57(9):615-20.

12. Arndt V, Rothenbacher D, Daniel U, Zschenderlein B, Schuberth S, Brenner H. Construction work and risk of occupational disability: a ten year follow up of 14,474 male workers. Occup Environ Med. 2005;62(8):559-66.

13. Welch LS, Hunting KL, Haile E, Boden LI. Impact of musculoskeletal and medical conditions on disability retirement-a longitudinal study among construction roofers. Am J Ind Med. In press.

14. Ware JE, Kominsky JR, Turner-Bowker DM, Gandek B. How to Score Version 2 of the SF-12 Health Survey. Lincoln (RI): QualityMetric Inc; 2002.

15. Lerner D, Amick BC III, Rogers WH, Malspeis S, Bungay K, Cynn D. The Work Limitations Questionnaire. Med Care. 2001;39(1):72-85.

16. Pransky G, Benjamin K, Hill-Fotouhi C, Himmelstein J, Fletcher K, Katz JN et al. Outcomes in work-related upper extremity and low back injuries: results of a retrospective study. Am J Ind Med. 2005;37:400-9.

17. Keogh JP, Gucer PW, Gordon JL, Nuwayhid I. Patterns and predictors of employer risk-reduction activities (ERRAs) in response to a work-related upper extremity cumulative trauma disorder (UECTD): reports from workers' compensation claimants. Am J Ind Med. 2000;38(5):489-97.

18. SAS Institute Inc. SAS for Windows, Release 9.1. Cary (NC): SAS Institute Inc; 2003.

19. Welch LS, Hunting KL, Haile E. Musculoskeletal and medical conditions among construction roofers. Am J Ind Med. In press.

20. Pengel LH, Herbert RD, Maher CG, Refshauge KM. Acute low back pain: systematic review of its prognosis. BMJ. 2003;327(7410):323 .

21. Enthoven P, Skargren E, Oberg B. Clinical course in patients seeking primary care for back or neck pain: a prospective 5year follow-up of outcome and health care consumption with subgroup analysis. Spine. 2004;29(21):2458-65.

22. Von Korff M, Deyo RA, Cherkin D, Barlow W. Back pain in primary care: outcomes at 1 year. Spine. 1993;18:855-62.
23. Thomas E, Silman AJ, Croft P, Papageorgiou AC, Jayson MI, Macfarlane GJ. Predicting who develops chronic low back pain in primary care: a prospective study. BMJ. 2005;318:1662-7.

24. Hagen KB, Tambs K, Bjerkedal T. A prospective cohort study of risk factors for disability retirement because of back pain in the general working population. Spine. 2002;27(16):1790-6.

25. Phillips H, Grant L. The evolution of chronic back pain problems: a longitudinal study. Behav Res Ther. 1991;29:435-41.

26. Cherkin DC, Deyo RA, Street J, Hollis S. Predicting poor outcome for back pain seen in primary care using patients' own criteria. Spine. 1996;21:2900-7.

27. Welch LS, Hunting KL, Nessel-Stephens L. Chronic symptoms in construction workers treated for musculoskeletal injuries. Am J Ind Med. 1999;36(5):532-40.

28. Pransky G, Benjamin K, Hill-Fotouhi C, Himmelstein J, Fletcher KE, Katz JN, et al. Outcomes in work-related upper extremity and low back injuries: results of a retrospective study. Am J Ind Med. 2000;37(4):400-9.

29. Krause N, Dasinger LK, Deegan LJ, Brand RJ, Rudolph L. Alternative approaches for measuring duration of work disability after low back injury based on administrative workers' compensation data. Am J Ind Med. 1999;35:604-18.

30. Dasinger LK, Krause N, Deegan LJ, Brand RJ, Rudolph L. Duration of work disability after low back injury: a comparison of administrative and self-reported outcomes. Am J Ind Med. 1999;35(6):619-31.

31. Karpansalo M, Manninen P, Lakka TA, Kauhanen J, Rauramaa $\mathrm{R}$, Salonen JT. Physical workload and risk of early retirement: prospective population-based study among middle-aged men. J Occup Environ Med. 2002;44(10):930-9.

32. Nordlund A, Ekberg K. Self reported musculoskeletal symptoms in the neck/shoulders and/or arms and general health (SF-36): eight year follow up of a case-control study. Occup Environ Med. 2004;61(3):e11.

33. Pransky G, Benjamin K, Savageau JA, Currivan D, Fletcher K. Outcomes in work-related injuries: a comparison of older and younger workers. Am J Ind Med. 2005;47:104-12.

34. Seland K, Cherry N, Beach J. A study of factors influencing return to work after wrist or ankle fractures. Am J Ind Med. 2006;49(3):197-203.

35. Krause N, Lynch J, Kaplan GA, Cohen RD, Goldberg DE, Salonen JT. Predictors of disability retirement. Scand J Work Environ Health. 1997;23(6):403-13.

36. Borg K, Hensing G, Alexanderson K. Predictive factors for disability pension - an 11-year follow up of young persons on sick leave due to neck, shoulder, or back diagnoses. Scand J Public Health. 2001;29(2):104-12.

37. Salonen $\mathrm{P}$, Arola $\mathrm{H}$, Nygård $\mathrm{CH}$, Huhtala $\mathrm{H}$, Koivisto AM. Factors associated with premature departure from working life among ageing food industry employees. Occup Med (Lond). 2003;53(1):65-8.

38. Stover B, Wickizer TM, Zimmerman F, Fulton-Kehoe D, Franklin G. Prognostic factors of long-term disability in a workers' compensation system. J Occup Environ Med. 2007;49(1):31-40.

39. Alavinia SM, van Duivenbooden C, Burdorf A. Influence of work-related factors and individual characteristics on work ability among Dutch construction workers. Scand J Work Environ Health. 2007;33(5):351-7.

40. Liira J, Matikainen E, Leino-Arjas P, Malmivaara A, Mutanen P, Rytkönen $\mathrm{H}$, et al. Work ability of middle-aged Finnish construction workers-a follow-up study in 1991-1995. Int J Ind Ergon. 2000;25:477-81.

41. Kujala V, Tammelin T, Remes J, Vammavaara E, Ek E, Laitinen 
J. Work ability index of young employees and their sickness absence during the following year. Scand J Work Environ Health. 2006;32(1):75-84.

42. Rothenbacher D, Brenner H, Arndt V, Fraisse E, Zschenderlein B, Fliedner TM. Disorders of the back and spine in construction workers: prevalence and prognostic value for disability. Spine. 1997;22(13):1481-6.

43. Welch LS, Hunting KL, Haile E. Musculoskeletal and medical conditions among construction roofers. Work. In press.

44. Dasinger LK, Krause N, Deegan LJ, Brand RJ, Rudolph L. Physical workplace factors and return to work after compensated low back injury: a disability phase-specific analysis. J Occup Environ Med. 2000;42(3):323-33.

45. Burdorf A, Frings-Dresen MHW, van Duivenbooden C, Elders LA. Development of a decision model to identify workers at risk of long-term disability in the construction industry. Scand J Work Environ Health. 2005;31(suppl 2):31-6.
46. Franche RL, Cullen K, Clarke J, Irvin E, Sinclair S, Frank J. Workplace-based return-to-work interventions: a systematic review of the quantitative literature. J Occup Rehabil. 2005;15(4):607-31.

47. Krause N, Dasinger LK, Neuhauser F. Modified work and return to work: a review of the literature. J Occup Rehabil. 1998;8:113-39.

48. de Boer AG, van Beek JC, Durinck J, Verbeek JH, van Dijk FJ. An occupational health intervention programme for workers at risk for early retirement; a randomised controlled trial. Occup Environ Med. 2004;61(11):924-9.

49. Hlobil H, Staal JB, Spoelstra M, Ariëns GA, Smid T, van Mechelen W. Effectiveness of a return-to-work intervention for subacute low-back pain [review]. Scand J Work Environ Health 2005;31(4):249-57.

Received for publication: 15 May 2008 